\title{
THE INDONESIAN PAVILION IN THE 1964 NEW YORK WORLD'S FAIR AS SUMMARY OF NATION-BUILDING PROJECTS
}

\author{
インドネシア国家建設事業の総括としての 1964 年ニューヨーク万国博覧会における \\ インドネシアパビリオンについて
}

Harry KURNIAWAN*1

ハリークルニアワン

\begin{abstract}
The Indonesian Pavilion in the 1964 New York World's Fair was built as a grand house for Indonesia's first participation in an international exposition after its independence. It was created from 1957-60s, which was enlivened by a series of monumental projects known as nation-building projects. The pavilion was the only luxurious structure built outside the country. While the nation-building project has been studied by scholars, an explanation of the Indonesian Pavilion has not yet been found. Therefore, this paper, by comparing nation-building projects and the Indonesian Pavilion, aims to describe the architectural characteristics of the Indonesian Pavilion and clarify its position as a nation-building project.
\end{abstract}

Keywords: Indonesian Pavilion, exposition, monument, Sukarno, modern architecture インドネシアパヴィリオン, エキジビション, 記念碑, スカルノ, 近代建築

1. Introduction

Indonesia is an active participant in many levels of international expositions. Since its independence in 1945 till 2017, fourteen participations have been recorded, with the 1964 New York World's Fair (NYWF) being the first*1). The Indonesian Pavilion in the 1964 NYWF — which will be referred to as 'Indonesian Pavilion' in this paper—was designed and built from 1961-64. It was during the peak years of the construction of buildings, monuments, and infrastructures under the Indonesian government's nation-building project (NBP). The NBP-also known as the character-building project—was known as a series of visionary projects to strengthen the 1957-65 Demokrasi Terpimpin ${ }^{* 2}$ ideology. The NBP's objective was 'to demonstrate the regime's commitment to a form of national discipline and the need to attract international recognition'*3). For achieving the objective, the NBP, through Sukarno's power, challenged Indonesia and its people-sometimes it included some foreigners involved in the project— to go beyond their limitations. The Indonesian Pavilion displayed several unique features compared to other NBPs. It was the only construction erected overseas while most NBPs were built in Jakarta, the capital and center of the struggle of the Indonesian people. The Indonesian Pavilion was built for temporary use with a temporal character while other NBPs were intended to be immortal or eternal. These facts trigger the curiosity to study further about the pavilion and generate questions about the position of the Indonesian Pavilion within NBPs and how it shared their characteristics.

The methodology to do this content analysis research was centralized on the analyses and discussions of literature as the main activity. It consists of textual and pictorial evidence related to NBPs and the Indonesian Pavilion. Collected data will be organized and compared in several topics framed to find the similarities, differences, and meaning of their architecture, as sound in Table 2. Several previous studies about NBPs, such as books and dissertation reports, were collected from Universitas Gadjah Mada Library (2018), Institut Teknologi Bandung Library (2015), and Badan Perpustakaan dan Arsip Daerah D.I Yogyakarta/Library and Archives Agency of D.I Yogyakarta Region (2018). Those complemented several archives of Sukarno' speeches, which were found in the Universitas Gadjah Mada Library, National Library of Republic of Indonesia, and the digital archive store (https://warungarsip.co/). Meanwhile, the Indonesian Pavilion used archives of the New York World's Fair 1964-1965 Corporation on Indonesian participation collected from visiting the New York Public Library in April 2016. Several newspaper articles and Sukarno's speech on Indonesian participation were collected from the National Library of the Republic of Indonesia and the National Archive of the Republic of Indonesia in 2016. There are several studies that cover NBPs, such as Sudradjat's (1999), Leclerc's (1993), Kusno's (2000), and Fakih's (2005). Sudradjat (1999) put the

*1 Doctoral Student, Dept. of Architecture and Building Science, Graduate School of Engineering, Tohoku Univ., M.Sc. / Lect., Dept. of Architecture and Planning,

東北大学大学院工学研究科都市 ·建築学専攻 博士後期課程 $/$

Faculty of Engineering, Universitas Gadjah Mada (Indonesia) ガジャマダ大学工学部建築計画学科＼cjkstart講師(インドネシア) 
discussion about NBPs as part his investigation on the historical development of Indonesian architectural history-especially in the context of the search for Indonesian architectural style - and how it took root and developed. Kusno (2000), in a chapter, offered a perspective on how NBPs shape and is shaped by the practices of architecture and urban design in the context of socio-cultural crisis in the postcolonial world. Leclerc (1993) discussed the meaning of the monuments and great works built by Sukarno in Jakarta from 1960 to 1966. Fakih (2005) illustrated Jakarta's development during Sukarno's presidency by describing the history of the city, the idea, the process, and the result of all NBP. However, none of those studies discussed the Indonesian Pavilion as part of an NBP. The description of the Indonesian Pavilion in the 1964 NYWF only appeared as a brief introduction to accompany the explanation of Indonesian participation in certain world expositions, such as exemplified in Pangestu's (2011) book entitled 'Our House: Indonesia Pavilion World Expo Shanghai 2011.' Therefore, this study can be a new reference to the architecture of the Indonesian Pavilion and complementary knowledge about the nation-building project.

\section{The Indonesian Pavilion in the 1964 New York World's Fair}

Indonesian participation in the 1964 NYWF was immense for several reasons. It was a two-floor building with 30,730 square feet that stood on a 40,000-square-foot lot. It took around $\$ 2.5$ million for the construction of the pavilion and $\$ 6.5$ million for the whole participations. Indonesia was noted as the $14^{\text {th }}$ country that announced its participation and the first country that signed the contract. It was the first participation of Indonesia after being independent of colonialization and it was prepared during the worst economic period. The motif of participation was to promote the country and, as explained by Sri Sultan Hamengku Buwono (HB) IX*4), the commissioner general for the pavilion of Indonesia, to further the aims of world peace, develop better international understanding, and promote harmonious international relations. The pavilion was framed with 'to build the world anew*5) as the theme. All this narration could be read as a reflection of "Indonesia's desire for creating a synthesis between Western and Eastern ideologies, in addition to [establishing] a new basis for world peace and international relations, based on the 'Five Principles,' or Pancasila (belief in God, humanity, nationality, democracy, and social justice), and would further give an impression of what Indonesia regards as its active and independent foreign policy*6)." The Indonesian pavilion could also be understood through some of the next statements. First, it was a reflection of "way of life; rich and dynamic culture; huge natural resources and the possibilities of exploiting them; contributions to world trade; and last but not least, efforts to attract foreign tourists ${ }^{* 7)}$." Second, it "was a showcase and a proof that Indonesia was not a backward country...on the verge of collapse, in a 'complete chaos' as argued by Neo-Colonialism, Colonialism and Imperialism Countries*8)." Third, it was one of the foremost instruments to declare and proclaim the Indonesian revolution*9).

The pavilion took an ultra-modern*10) image in which the physical characteristic of its architecture could be described by the appearance of:

a. The 86-foot high Candi Bentar ${ }^{* 11}$ as the gate to the site.

b. A "Meru ${ }^{* 12}$ ") structure and a lotus-filled pond between the gate and the building to create Indonesia's "watery country" image and atmosphere.

c. A two-floor main structure with a circular form.

d. A roof shaped like an umbrella.

e. The beams of the radial frame of the roof converge at the axis and then spread out again the form of a 61 -foot high five-petal flower. From within the flower, five shafts of colored light point skyward.

f. Ornamented with traditional elements and motifs.

This grand pavilion was entrusted directly by Sukarno to R.M.

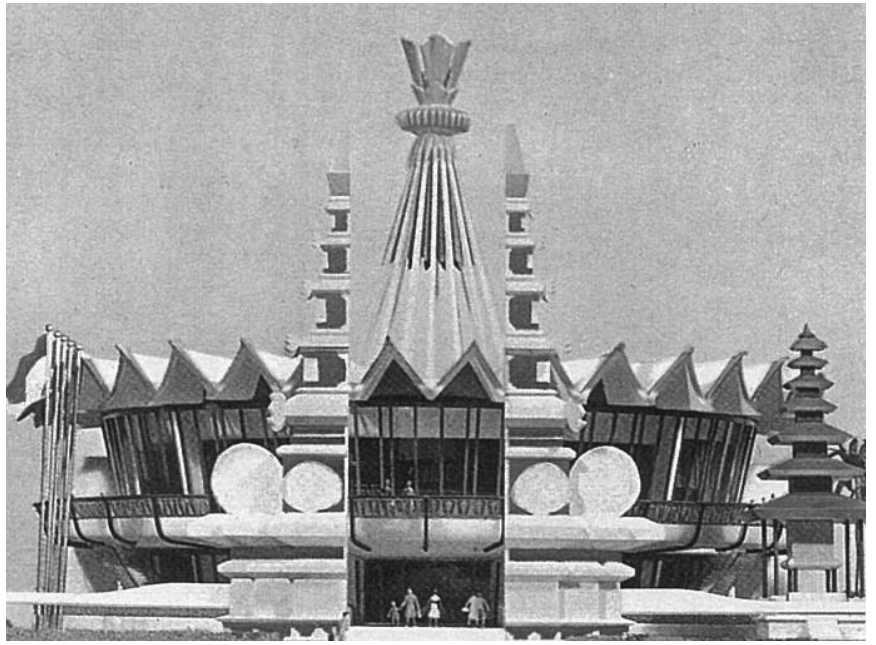

Fig. 1 The Architecture of Indonesian Pavilion

Soedarsono who was the palace architect and had experiences to interpret Sukarno's assignments under the nation-building projects category, such as the Tugu Nasional (National Obelisk). Sukarno was either assigned Abel Sorensen, an American architect who built the first modern hotel in Indonesia, Hotel Indonesia, as consulting architect, and Max O. Urbahn, as local partner. The design process lasted from September of 1961 (site selection) to the end of 1962 with the groundbreaking phase done on the $18^{\text {th }}$ of January 1963. Then, its opening was preceded by "Slamatan" (pre-opening dinner party) in the evening of 19th April 1964. This building was occupied by four themed (political, cultural, trade, and tourism) exhibitions, demonstration of handicrafts, a souvenir shop, and a restaurant with oriental dancers and a native orchestra. All efforts received much appreciation from the media and visitors. It hit newspaper headlines several 
times and became 'one of the fair's most popular during the 1964 season*13)' by surpassing the number of visitors to pavilions representing South and Southeast Asia and the Far East, and several other foreign pavilions*14).

\section{Sukarno and Nation-Building Projects}

Sukarno, the first president of Indonesia, was a charismatic figure who led the diplomatic fight against colonialization and was appointed to proclaim independence - together with Muhammad Hatta- on August $17^{\text {th }}$, 1945. Sukarno was admired by the national and international community. Sukarno, in fact, was educated in architecture at Technische Hoogeschool (TH) in Bandung (now known as the Insitute Teknologi Bandung), and even worked as a professional architect through apprenticeship in Wolff Schoemaker's architecture office-a well-known Dutch architect who worked in the Netherlands-Indies and professor at $\mathrm{TH}$-and established an architecture office with his classmate, Ir. Anwari, in 1926. He even said to Prof. Schoemaker in his early graduation period that his 'destiny is to be an architect of a nation*15)' and he revived his destiny to support his idea of revolution*16), which consisted of destruction and construction (pembangunan) and-for pembangunanrequired creativity and architect-minded people.
Table 1 Sukarno's nation-building projects which were built

\begin{tabular}{|c|c|c|c|}
\hline No & $\begin{array}{l}\text { Building Name } \\
\end{array}$ & Year / Designer & Location \\
\hline A. & Functional Type & & \\
\hline 1 & $\begin{array}{l}\text { Gelora/Asian Games Stadium } \\
\text { (GAGS) }\end{array}$ & 1961-62/L.S. Tyatenko (Russia) & \multirow{7}{*}{ Jakarta } \\
\hline 2 & Hotel Indonesia (HI) & 1959-1962/Abel Sorensen (U.S) & \\
\hline 3 & $\begin{array}{l}\text { Sarinah Department Store } \\
\text { (SDS) }\end{array}$ & $\begin{array}{c}\text { 1966/ Kinoshita and Taisei } \\
\text { Corporation (Japan) }\end{array}$ & \\
\hline 4 & Masjid Istiqlal (MI) & 1954-1978/ F. Silaban & \\
\hline 5 & Wisma Nusantara (WN) & $\begin{array}{c}\text { 1964/ Kinoshita, Kajima, and Taisei } \\
\text { Corporation (Japan) }\end{array}$ & \\
\hline 6 & $\begin{array}{c}\text { Conefo Building (CB) - now the } \\
\text { Parliament House }\end{array}$ & 1965 /Sujudi & \\
\hline 7 & $\begin{array}{c}\text { Gedung Pola (GP) / Pola } \\
\text { Building } \\
\end{array}$ & 1961-63/ F. Silaban & \\
\hline 8 & Pavilion for 1964-1965 NYWF & 1963-1964/ Soedarsono & $\begin{array}{l}\text { New York, } \\
\text { U.S }\end{array}$ \\
\hline 9 & Ambarukmo Hotel & $1960-1965 /-$ & Yogyakarta \\
\hline 10 & $\begin{array}{l}\text { Bali Beach Hotel (now - Inna } \\
\text { Grand Beach Hotel) }\end{array}$ & $\begin{array}{l}\text { 1963-1966/ Taisei Construction } \\
\text { (Japan) \& PN. Pembangunan } \\
\text { Perumahan (PP) }\end{array}$ & Bali \\
\hline 11 & $\begin{array}{c}\text { Samudra Beach Hotel, } \\
\text { Pelabuhan Ratu }\end{array}$ & \begin{tabular}{|c} 
1962-1965/ PN PP and Taisei Kanko \\
Kabushiki Kaisha Ltd. (Japan)
\end{tabular} & West Java \\
\hline \multicolumn{4}{|c|}{ B. Memorial Type } \\
\hline 1 & \begin{tabular}{|l} 
Tugu Nasional (TN) \\
\end{tabular} & 1961-75/ Soedarsono & \multirow{4}{*}{ Jakarta } \\
\hline 2 & Tugu Dirgantara (TD) & 1964-65/ Ir. Sutami - Edhi Sunarso & \\
\hline 3 & $\begin{array}{c}\text { Tugu Pembebasan Irian Barat } \\
\text { (TPIB) }\end{array}$ & $\begin{array}{c}\text { 1963/F. Silaban- Henk Ngantung\& } \\
\text { Edhi Sunarso }\end{array}$ & \\
\hline 4 & Tugu Selamat Datang (TSD) & $\begin{array}{c}\begin{array}{c}\text { 1962/ Henk Ngantung- Edhi } \\
\text { Sunarso }\end{array} \\
\end{array}$ & \\
\hline
\end{tabular}

Projects—under the name of nation-building or character-building projects (original English for both)—were initiated 'to recover our national identity*17)', which Sukarno (1963) said as important as the problem of food and clothing*18), and to put Indonesia in a similar position as other country. Several landmarks were built to transform Jakarta, which was the center of the struggle of the Indonesian people, into an inspirational city, beacon to struggling mankind and the emerging forces, and the portal of the country (Sukarno, 1962). Some landmarks were made for Sukarno's visionary motif, such as Hotel Indonesia—the first modern hotel with 14 stories and 423 rooms designed by American Architect Abel Sorensen; Wisma Nusantara - the first modern office building in Indonesia and highest building in Asia (29 floors) at that time; the Jakarta By-pass—-the first modern interchange and highway in Indonesia; the 500-hectare Ancol Recreation Complex - the biggest project and recreation place in Southeast Asia; and several other buildings, monuments, and infrastructure. Meanwhile few projects, such as Ambarukmo Hotel in Yogyakarta and Bali Beach Hotel in Bali, were also built out of Jakarta (see Table 1).

The objective of NBP was translated using modern architectural language in the projects, as it was either used in many countries during that time. Sukarno saw this architectural language as an appropriate tool to 'blot out the lingering images of the colonial past*19)'. He stated his admiration of modern architecture by explaining Brasilia and Oscar Niemeyer-a new modernist city and architect-during the commemoration of the 435th anniversary of the city of Jakarta*20). Frederich Silaban, an architect who helped Sukarno realize his NBP and shared the same vision about architecture, said that 'modern architecture can describe (or at least portray) Indonesia's identity'*21). Admiration of modern architecture can be found implemented in the NBP's design strategies—as

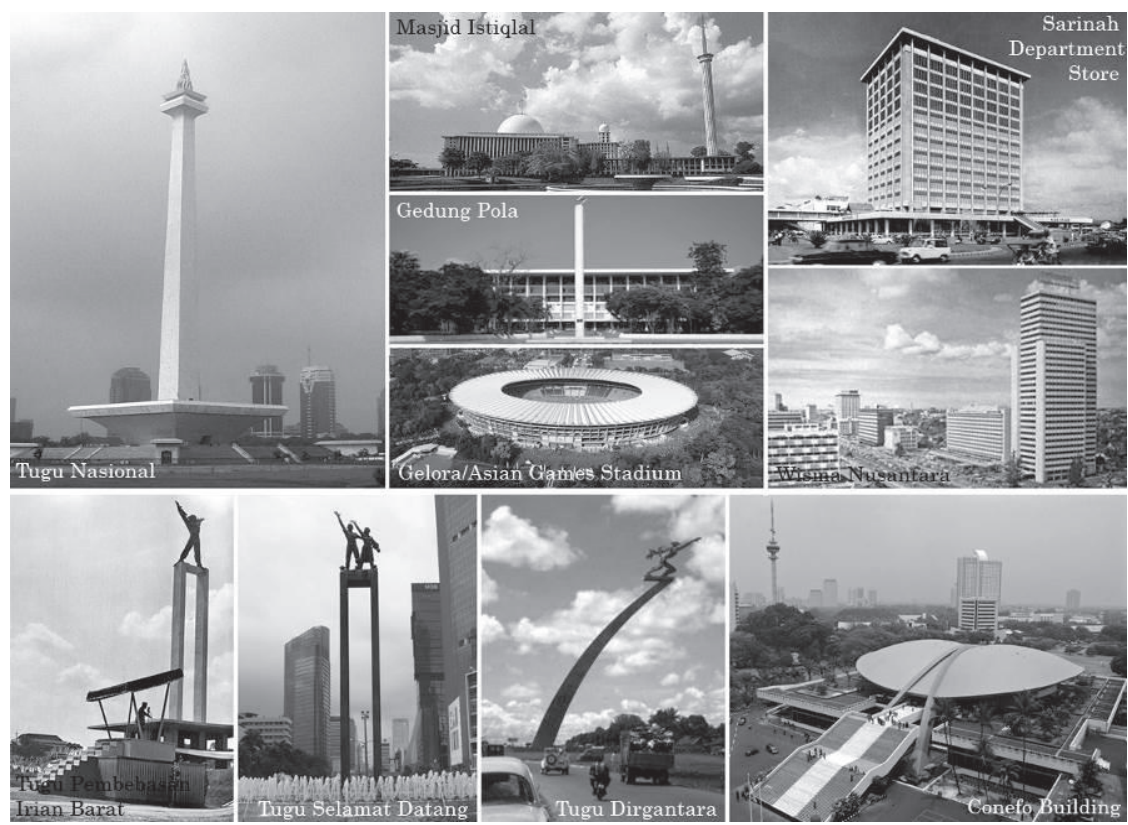

Fig. 2 Buildings and Obelisk in Nation-Building Project Series 
compiled in Table 2. The strategy to situate the building at the center of the site (such as in Gelora/Asian Games Stadium, Tugu National, Tugu Dirgantara, Tugu Pembebasan Irian Barat, and Tugu Selamat Datang) or pulled back from the site entrance (such as in Hotel Indonesia, Sarinah Department Store, Masjid Istiqlal, Gedung Pola, and Conefo Building) was arranged so the building could be seen as a three-dimensional statue. Sometimes, it was also strengthened by the appearance of a big pool in the courtyard to present a full reflection of the building. Modern architectural forms that give a freshness look were implemented in many functional and memorial-type buildings through simplified geometry. A small number displayed the used of sculptural form to generate surprising meaning to the user or viewer-which was a strategy used commonly by Niemeyer, such as at Conefo Building and Tugu Nasional (see Table 2). This modern architectural form was followed by the use of concrete and metal roof material and form-which was a common act—to replace the use of common form (such as pyramid and gable) and material (clay, wood, or straw) found in buildings in Indonesia at that time. Another strategy promoted by Niemeyer that could be found in NBP is the integration of the arts into the architecture and landscape design. All memorial-type buildings crowned their monuments with big figurative statues, such as human figures in Tugu Dirgantara, Tugu Pembebasan Irian Barat, and Tugu Selamat Datang or the flame in Tugu Nasional (see Table 2 and Figure 2). Some small statues or sculptures were installed on the landscape around some buildings to strengthen the symbolic meaning of the buildings.

\begin{tabular}{|c|c|c|c|c|c|c|c|c|c|c|c|c|}
\hline \multirow{4}{*}{$\mathrm{No}$} & \multirow{4}{*}{ Characteristic } & \multicolumn{6}{|c|}{ Functional-Type Building } & \multirow{4}{*}{$\begin{array}{l}\text { Indonesia } \\
\text { Pavilion }\end{array}$} & \multicolumn{4}{|c|}{ Memorial-Type Building } \\
\hline & & Gelora/Asian & Hotel & Sarinah & Masjid C & Gedung & Conefo & & Tugu & Tugu & Tugu & Tugu \\
\hline & & Games I & Indonesia & Department & Istiqlal & Pola & Building & & Nasional & Dirgantara & Pembebasan & Selamat \\
\hline & & $\begin{array}{c}\text { Stadium } \\
\text { (GAGS) }\end{array}$ & (HI) & Store (SDS) & (MI) & & (CB) & & $(\mathrm{TN})$ & (TD) & $\begin{array}{c}\text { Irian Barat } \\
\text { (TPIB) }\end{array}$ & $\begin{array}{l}\text { Datang } \\
\text { (TSD) }\end{array}$ \\
\hline \multicolumn{13}{|c|}{ Building Design } \\
\hline & $\begin{array}{l}\text { Location on the site } \\
\text { (Center = C; Setback = S) }\end{array}$ & $\mathrm{C}$ & $\mathrm{S}$ & $\mathrm{S}$ & $\mathrm{S}$ & $\mathrm{S}$ & $\mathrm{S}$ & $\mathrm{C}$ & $\mathrm{C}$ & $\mathrm{C}$ & $\mathrm{C}$ & $\mathrm{C}$ \\
\hline \begin{tabular}{|l|l|}
2 \\
\end{tabular} & Program/Function & $\mathrm{V}$ & $\mathrm{V}$ & $\mathrm{V}$ & $\mathrm{V}$ & $\mathrm{V}$ & $\mathrm{V}$ & $\mathrm{V}$ & $\mathrm{V}$ & - & - & - \\
\hline \multicolumn{13}{|c|}{\begin{tabular}{|l|l|}
3 & Form \\
\end{tabular}} \\
\hline & a. Simplified geometric form & $\mathrm{V}$ & $\mathrm{V}$ & $\mathrm{V}$ & $\mathrm{V}$ & $\mathrm{V}$ & - & - & - & $\mathrm{V}$ & $\mathrm{V}$ & $\mathrm{V}$ \\
\hline & b. Sculptural form & - & - & - & - & - & $\mathrm{V}$ & - & - & - & - & - \\
\hline & $\begin{array}{l}\text { c. Sculptural form with traditional } \\
\text { precedent/meaning }\end{array}$ & - & - & - & - & - & - & $\mathrm{V}$ & $\mathrm{V}$ & - & - & - \\
\hline \multicolumn{13}{|c|}{4 Roof } \\
\hline & a. Concrete roof $($ flat $=\mathrm{F} ;$ curved $=\mathrm{C})$ & - & $\mathrm{F}+\mathrm{C}$ & $\mathrm{F}$ & $\mathrm{F}+\mathrm{C}$ & $\mathrm{F}$ & $\mathrm{C}$ & - & $\mathrm{F}$ & - & - & - \\
\hline & b. Metal roof & $\mathrm{V}$ & - & - & - & - & - & $\mathrm{V}$ & - & - & - & - \\
\hline \multicolumn{13}{|c|}{5 Local architectural elements or principles } \\
\hline & b. Ventilation block/louvers & $\mathrm{V}$ & $\mathrm{V}$ & $\mathrm{V}$ & $\mathrm{V}$ & - & $\mathrm{V}$ & $\mathrm{V}$ & - & - & - & - \\
\hline & c. $\quad$ Traditional ornaments & - & - & - & - & - & - & $\mathrm{V}$ & - & - & - & - \\
\hline & $\begin{array}{l}\text { Symbolic elements attached to the } \\
\text { structure }\end{array}$ & - & - & - & - & - & - & $\mathrm{V}$ & $\mathrm{V}$ & $\mathrm{V}$ & $\mathrm{V}$ & $\mathrm{V}$ \\
\hline \multicolumn{13}{|c|}{ Features of the Yard } \\
\hline & Sculpture & $\mathrm{V}$ & - & - & - & $\mathrm{V}$ & $\mathrm{V}$ & $\mathrm{V}$ & $\mathrm{V}$ & - & - & - \\
\hline 2 & Pool & - & - & - & $\mathrm{V}$ & - & $\mathrm{V}$ & $\mathrm{V}$ & $\mathrm{V}$ & - & - & - \\
\hline
\end{tabular}

\section{Characteristic of Indonesian Pavilion as part of Nation-Building Project}

\subsection{Sukarno's involvements}

One main character of the NBPs was the intense involvement of President Sukarno in the projects. His involvement could be found during project initiation, architect selection, the design process, the construction process, as well as him echoing the importance of the projects in his speeches ${ }^{* 22}$. In the initiation phase, Sukarno could urge that project be built—such as with Gelora Stadium, Conefo Building, Gedung Pola, and Tugu Dirgantara—or he could elevate the value of the project such as in Tugu Nasional*23) and Masjid Istiqlal*24). In the design process, Sukarno showed several ways to get the best design to fit his vision, such as requesting a design directly from his trusted architects—-such as Soedarsono and Silaban—and artists—such as Henk Ngantung and Edhi Sunarso—or holding open competitions where Sukarno led the jury committee-such as for Masjid Istiqlal, Conefo Building, and Tugu Nasional. The complete illustration for this is the process behind the Tugu Nasional project where Sukarno himself stood to brief architects, artists, and engineers during the opening of a nationwide contest for a Monumen Nasional (National Monument), then led the project committee and the jury team in the first and second competition - with no first winner for both, then directly assigned Soedarsono and Silaban to propose the final design, and finally chose the design made by Soedarsono to be realized (Salam, 1989). Another example could be seen in the design of the statue of Tugu Dirgantara, which was a redraw of Sukarno's pose, which he did during the explanation of his instruction to build the monument*25). Sukarno also did not hesitate to direct the architect or artist in order to meet his vision for NBP, as Sukarno's instruction note was found on a design drawing of Wisma Nusantara to set the building's wings back by 30 percent ${ }^{* 26)}$, or Sukarno's sketch with the note 'Sdr. Henk! Begini lo! (Brother Henk! Follow this way!)' for Tugu Pembebasan Irian Barat given to Henk Ngantung, 
the artist*27). During the construction phase, Sukarno repeatedly made site visits*28) and even donated some of his own money*29). The ‘Acc Soek (Sukarno's approval)' phrase, which marked Sukarno's involvement, could be found in many documents in different phases*30).

The Indonesian Pavilion displayed a similar characteristic of Sukarno's involvement, as he explained in his welcoming speech for the delegation that returned from NYWF on November 21, 1964*31). He stated his reason for deciding to participate, his appearance at the park to choose the site for the Indonesian Pavilion*32), and his intention to choose the delegated aides by himself. Further, Sukarno's involvement could be seen in many aspects of the pavilion's design and exhibition. Ho (1963) wrote in his newspaper article that 'the State Housing Development Company has been assigned to plan the pavilion and its landscaping under the supervision of President Sukarno.' Sukarno had 'especially requested this (Candi Bentar) gate, and indeed helped design it*33)' The whole concept of the pavilion's architecture was developed from Sukarno's speech in front of the United Nations General Assembly on September 30, 1960*34). The speech's title, 'To Build the World Anew, became the political theme for the Indonesian Pavilion*35). He requested that a roof tower is added to the pavilion*36) and presented a painting he made in $1958^{* 37)}$ as one of the main exhibited material. His intense involvement was concluded by his 'order to close down*38)' the pavilion and cancel Indonesia's participation commitment in the 1965 NYWF in his anger toward America for supporting Malaysia during the Indonesia-Malaysia confrontation period.

\subsection{Monument and Monumentality}

Leclerc ${ }^{* 39)}$ said that a structure was made a monument by an epic narration and moment. He continued that 'monuments are epic, have an epic function, and stand as the nation's epic in the nation's figurative center, the capital city'. Nation-building projects, as monuments, were built in the form of buildings, obelisks, statues, and infrastructure. As a series of projects, NBPs were a monument to re-build the people's spirit*40), including the self-confidence of Indonesian artists who were relegated to minor works during colonial times into major three-dimensional outdoor works ${ }^{* 11}$. This could be found in the purpose of the construction of Hotel Indonesia, the Wisma Nusantara office building, Sarinah Department Store, a sports complex, main street of Jakarta, and big infrastructure to project Indonesia as "the beacon of the new Emerging Forces*42)" to people who came during the Asian Games in 1962 and the 1963 Games of the New Emerging Forces (GANEFO) (see also explanation in part 3). The fact that only part of them was used or occupied after the completion was evidence that their existence was more essential than their use. Tugu played this commemorative meaning more visually. The Tugu Selamat Datang/'Welcome Obelisk' was part of the commemoration of the 1962 Asian Games and the 1963 GANEFO. The Tugu Pembebasan Irian Barat/Liberation of West Irian Obelisk was initiated by Sukarno to encourage the struggle to liberate West Irian from Dutch colonialism at that time. The Tugu Dirgantara/Aerospace Obelisk was initiated in 1964 by Sukarno to commemorate and honor Indonesian aviator heroes. The word symbolic, was also frequently used by Sukarno to strengthen his idea about the function of a monument, as read in Sukarno's explanation on Tugu Nasional. Sukarno said that "Tugu itself is a symbol of virile grandeur and bravery." Tugu Nasional was intended to be a monument to the Indonesian nation's valor; "an emblem of the people's will to soar on high", an emblem of "rising up to the firmament", in short, 'lambang Revolusi Indonesia $\left.{ }^{*}+3\right)$ '. The Indonesian Pavilion clearly stood at the center of the international community/pavilions to be a monument of the Indonesian revolution. For this purpose, it, as has been described in part 2, displayed what Indonesia had (cultural and natural diversity and richness, and ideology) and wanted to reach (modern built environment and society). This could be seen through the collage of different symbolic elements in the participation and the architecture, such as the traditional architecture and culture appearing side by side with modern architecture and culture, the appearance of Pancasila tower and Indonesian natural elements (such as water), the collaboration between Indonesian architects and foreign architects, and the appearance of Sultan HB IX of Yogyakarta*44) - the leader of the traditional government system - at the Indonesian Pavilion's groundbreaking in 1963 and as the commissioner general to represent Indonesia.

The NBP was identic with monumentality, which is an image of the concept of grandeur

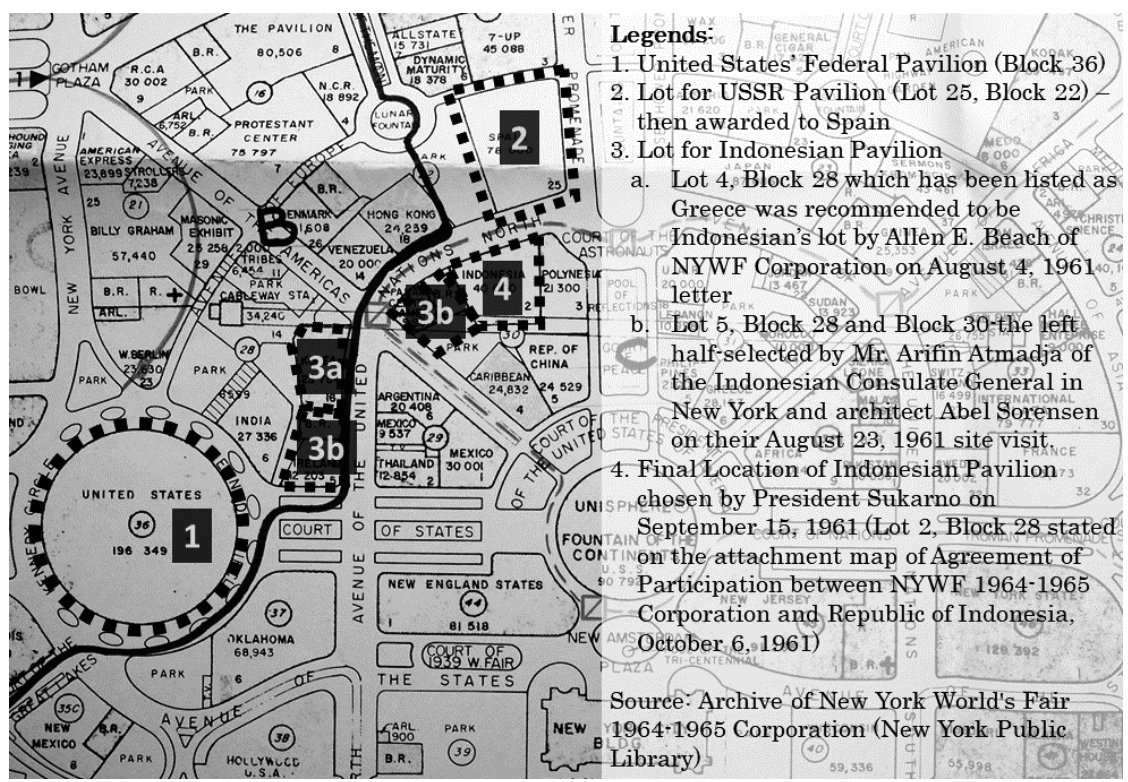

Fig. 3 The location of the Indonesian Pavilion during the 1964 NYWF 
achieved through combining quality of form and its location on the site. Holston gave one of modern architecture's common strategies to achieve monumentality by saying 'the buildings are all freestanding objects, and, as such, they are all monumental ${ }^{* 45)}$.' The space or distance provided visitors with a chance to see and enjoy the building as a three-dimensional structure. This was found in the NBP's building and the Indonesian Pavilion (see Table 2), where buildings were in the center of the site or pulled back from the sites border. The importance of this strategy was exemplified in Wisma Nusantara's project, as explained in part 4.1, and in Sukarno's speeches*46).

\section{Unique Characteristics of the Indonesian Pavilion}

\subsection{Meaningful form}

Form was indispensable to modernist discourse where 'architect' was strongly translated as 'form-giver*47)' One of the reasons for 'form' to be adopted and made a cardinal term in architectural modernism was because 'it was not a metaphor*48'. The NBP displayed the use of modern architectural form through the domination of simplified geometric form without historical connotation. It could be seen mostly in the NBP's functional type building, such as GAGS, MI, HI, and the main structure of the memorial type building. However, there are buildings that create form through precedent and symbolism. Those are Tugu Nasional and the Indonesian Pavilion. Tugu Nasional was identified as a single-volume building with sculptural quality form. It took lingga-yoni form as precedent, so it could deliver the asked narration as a national monument. Lingga-yoni, as explained by Soedarsono in Salam (1989), is the symbol from ancient times to portray eternal life that consists of eternal positive elements (lingga) and negative elements (yoni) in the world, such as the existence of day and night, male and female, and good and bad. It was an answer to Sukarno's requirement*49) on the design of Tugu Nasional, which that can describe Indonesian personality and illustrate the dynamics of Indonesia. Meanwhile, the circular form of the Indonesian Pavilion was made to strengthen the statement of the political and ideological neutrality of Indonesia. This design was triggered by Sukarno's decision and reason to choose a neutral site located an equal distance ${ }^{* 50)}$ from the U.S and U.S.S.R. sites.

\subsection{Utilitarian Tugu/Obelisk}

The symbolic element, named the Pancasila Tower, was attached on an important position on the Indonesian Pavilion. The tower was around 35 meters high from the ground and stood on top of the roof. As it was named, the tower was purposed to symbolize the five points of guidance of life of Indonesia as a nation, Pancasila. Pancasila is a guidance of life that was informed and even proposed by Sukarno as an alternative besides two values, democracy and communism, which dominated and were at war at that time. It took the form of a flower with five petals that light would come out of and shoot to the sky. The importance of the tower was displayed by the long process of the design, as indicated by the timeline of published images and correspondence. It was mentioned in the minutes for the Conformity Committee Meeting, which was dated April 30 $0^{\text {th }}$, 1962, but the image did not appear in the Indonesian Pavilion's image in August 1963's The Concrete Era magazine (see Fig. 4). However, a photo of the design from the 1963 New York World's Fair 1964-1965 Corporation, as seen in Figure 5, illustrated the idea for the tower, which was written on the correspondence letter as 'a free-standing tower on top of the building with a hand

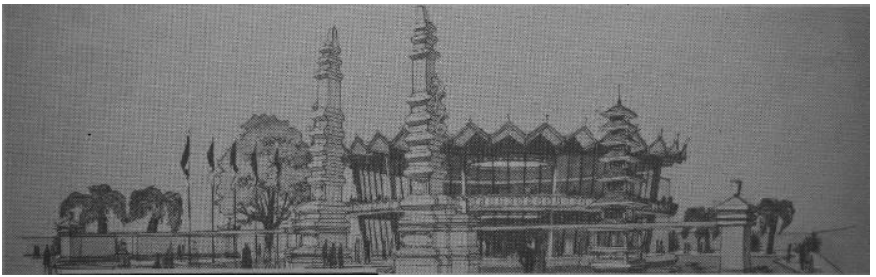

Fig. 4 Illustration of the Indonesian Pavilion in a1963 magazine

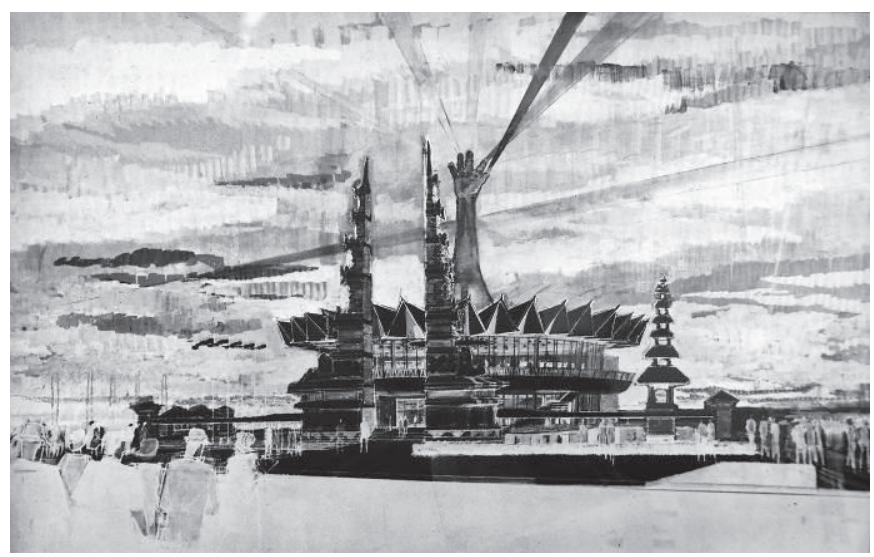

Fig. 5 'Hand' sculpture in the early design of the Indonesian Pavilion symbolizing the five freedoms of Indonesia*51)' The hand figure in the earlier scheme referred to the social realist style, which was found in the human figure sculptures of Tugu Dirgantara, Tugu Pembebasan Irian Barat, and Tugu Selamat Datang. The final design, which was a simplified form of the original, could be paired with the gold fire flame sculpture of Tugu Nasional. Furthermore, the location of the symbolic element as the crown of the structure strengthened the similarity between the Indonesian Pavilion and memorial-type buildings such as Tugu Nasional, Tugu Selamat Datang, Tugu Pembebasan Irian Barat, and Tugu Dirgantara. However, the Indonesian Pavilion had spaces to accommodate several defined programs, which was comparable to a functional-type building and its program as the generator of its architecture. This duality could only be compared to Tugu Nasional, which was decided by Sukarno 'to house the 'sacred relic', Bendera Pusaka Sang Dwiwarna, the very red and white flag that had been hoisted at Pengangsaan Timur on 17 August 1945*52).' Therefore, the symbolic element and designated program are identified as the uniqueness of the Indonesian Pavilion. 


\subsection{The juxtaposition of modernity, tradition, and art}

Sukarno put the NBP as a monument that should be read in its specific context, which consisted of time (event) and place-Indonesia in general. This was exemplified by the competition brief of Monumen Nasional, which was used as a complex that consisted of the main building, called Tugu Nasional, and several annexes built in the center of Independence Square. In a larger context, Sukarno visualized Jakarta - with its NBP_to be a lighthouse (monument) for Indonesia, New Emerging Forces countries, and the world. The relationship between a structure of an NBP and its context could be brought to understand the stressing use of modern architectural language over traditional architectural language for those structures. The context has provided values of traditions or localities for the urgency of modern structural construction. However, some NBP buildings still display the use of indigenous architectural principles and elements, such as long overhanging roofs and ventilation blocks, which were added as the second skin of the buildings. Both were taken from indigenous architectural principles to provide shading from direct sunlight and heavy rain, and good air circulation.

The Indonesian Pavilion has a similar basic attitude on using modern architectural language but, at the same time, it displayed extensive use of Indonesian tradition and art. Abel Sorensen, consulting architect for the Indonesian Pavilion, in his letter dated March 20th, 1962, to Mr. Gates Davison from NYWF Corporation, delivered the desire of Indonesia's government for contemporary design reflecting their progressive aims, as well as their cultural art forms. Even, a complete Minangkabau or other indigenous dwellings were planned to be placed within it as part of a historic exhibition. The extensive use of tradition and art in the Indonesian Pavilion could be seen in some forms. First, the traditional element was not only attached but also redesigned, such as the circular pitch roof, which was said to have taken the shape of a traditional umbrella and the abstraction of watery country through the pond that separated the entrance gate and the main building (connected by a bridge). Second, it used traditional ornaments in more places. Third, it installed an imitation of traditional architectural elements (Candi Bentar gate and Meru tower) as free-standing fixtures in its yard. These freestanding traditional elements, especially, were not found in other NBPs. As the whole, these forms created a bold juxtaposition of modern architectural language, tradition, and art. The reason for this bold juxtaposition could be read by recalling the structure-context relationship. The context, which pictured the identity and condition of Indonesia at that time, was not provided by the NYWF' site, and, therefore, it had to be created to give full narration for the modern designed pavilion. The extensive use of traditional elements, especially with the installment of the Candi Bentar gate and Meru tower, was the fastest way to represent the image of Indonesia to visitors.

\section{Conclusion}

The Indonesian Pavilion in the 1964 NYWF was in line with other nation-building projects. Similar basic characteristics, such as modern architectural language and monumentality, maintained the quality as an instrument of Sukarno's 1957-65 Demokrasi Terpimpin. The similar design process, which involved Sukarno's touch, was found in all the projects in the NBP series. The Indonesian Pavilion and other NBPs clearly display Sukarno's position as The Guider in the Demokrasi Terpimpin that led the design and people who worked in those projects to create the same manifestation of the NBP's vision. However, the characteristic of the architecture of the Indonesian Pavilion led to the conclusion that the pavilion went beyond the limitation of a functional building and memorial-type project. The appearance of a symbolic sculpture, which was the main characteristic of a memorial-type project, together with a defined program, which was the generator of the design of the functional building type, was strengthened by the meaningful form- which was identified as the opposite nature of modern architecture—of the Indonesian Pavilion's main structure and the extensive use of traditional elements and art. Furthermore, this unique characteristic of the Indonesian Pavilion did not eliminate it from the NBP but, instead, supported it as 'an inspiration and beacon to the whole of struggling mankind and to all the emerging forces, and as the portal of the country' - the purpose of the NBP's construction, as explained by Sukarno (1962). The context of place (overseas), time (temporary), and audience (foreigner) that framed the Indonesian Pavilion explained the ease of knowing and understanding Indonesia in a short time as the main consideration of the appearance of this unique characteristic. Finally, this unique characteristic explains the phrase 'ultra-modern' style and brings the conclusion of the Indonesian Pavilion as a summary of the nation-building project.

\section{Acknowledgments}

This study is supported by the Directorate General of Higher Education (DGHE)—Ministry of Education and Culture, Republic of Indonesia-Scholarship. 


\section{References}

1) Damais, Soedarmadji J.H.: Karya Jaya: Kenang-Kenangan Lima Kepala Daerah Jakarta 1945-1966 (Masterpiece: Memoires of the Five Governors of Jakarta 1945-1966), Jakarta: Pemerintah DKI Jakarta, 1977 (in Indonesian)

2) Fakih, Farabih: Membayangkan ibukota Jakarta di bawah Soekarno (Imagine the capital of Jakarta under Soekarno), Ombak, 2005 (in Indonesian)

3) Forty, Adrian: Words and Buildings: A Vocabulary of Modern Architecture, London: Thames \& Hudson Ltd, 2000

4) Harian Merdeka: Paviljun Indonesia Salah Satu Front Terdepan untuk Kumandangkan dan Mentjanankan Revolusi Kita (Indonesian Pavilion is One of the Foremost Instrument to Declare and Proclaim the Indonesian Revolution), Harian Merdeka (newspaper), 1964.6.22, p. 2 (in Indonesian)

5) Ho, Sie Pek: Indonesia Plans N.Y.Fair Exhibit, The Christian Science Monitor, 1963.1.10

6) Kusno, Abidin: Behind the Postcolonial: Architecture, Urban Space, and Political Cultures in Indonesia, London: Routledge Kegan Paul, 2000

7) Leclerc, Jacques: Mirrors and The Lighthouse: A Search for Meaning in the Monuments and Great Works of Sukarno's Jakarta, 1960-1966, in P. Nas (ed.): Urban Symbolism, Vol. 8, Studied in Human Society, Brill, 1993, pp. 38-58

8) New York World's Fair 1964-1965 Corporation: Groundbreaking at the New York World's Fair 1964-1965: The Pavilion of Indonesia, January 18, 1963 (transcript), New York: New York World's Fair 1964-1965 Corporation, 1963.a

9) New York World's Fair 1964-1965 Corporation: Architecture of The Indonesian Pavilion New York World's Fair, 1964-1965, New York: New York World's Fair 1964-1965 Corporation, 1963.b

10) Pangestu, Mari Elka. [ed.]: Our House: Indonesia Pavilion World Expo Shanghai 2011, Jakarta: PT. Gramedia Pustaka Utama, 2011

11) Papadaki, Stamo: Oscar Niemeyer, New York: George Braziller, Inc, 1960

12) Pusat Dokumentasi Arsitektur: Tegang Bentang: Seratus Tahun Perspektif Arsitektural di Indonesia (Tegang Bentang: One Hundred Years of Architectural Perspective in Indonesia), Jakarta: PT. Gramedia Pustaka Utama, 2003 (in Indonesian)

13) Salam, Solichin: Tugu Nasional dan Soedarsono (National Obelisk and Soedarsono), Jakarta: Kuningmas, 1989 (in Indonesian)

14) Silver, Christopher: Planning the Megacity: Jakarta in the Twentieth Century, New York: Routledge, 2008

15) Sudradjat, Iwan: A Study of Indonesian Architectural History. PhD Thesis (unpublished), Sydney University, 1991

16) Sukarno: Amanat Presiden Sukarno pada peringatan Ulang Tahun ke-435 kota Djakarta di Gedung Olah Raga Djakarta pada tanggal 22 Juni 1962 (The Mandate of President Sukarno at the commemoration of the 435th anniversary of the city of Djakarta at Djakarta Sports Hall on June 22, 1962), Jakarta: Departemen Penerangan, 1962 (in Indonesian)

17) Sukarno: 'Ambeg Parama-Arta', Jakarta: Departemen Penerangan Republik Indonesia, 1963

18) Sukarno: Pidato PJM Presiden Sukarno Dihadapan Para Utusan Jang Telah Kembali dari New York World Fair (The Speech of PJM President Sukarno in front of delegation who has been returned from New York World Fair), Bogor, 21 November 1964, Sekretariat Negara-Kabinet Presiden Republik Indonesia, 1964 (in Indonesian)

19) Susanto, Mikke (ed.): Edhi Sunarso: Seniman Pejuang (Edhi Sunarso: Patriot-Artist), Yogyakarta: PT. Hasta Kreatifa Manunggal, 2010

20) The Information Division of the Indonesian NYWF Committee: Press Release of Ambassador Zairin Zain's-Indonesian ambassador to the United States-speech, the Indonesian NYWF Committee, 1964.5.8

\section{Image Sources}

Fig. 1. Time-Life Books [ed.]: Official Guide, New York World's Fair 1964/1965. New York: Time Incorporated, 1964

Fig. 2. Author's photo and collection of photos from various websites

Fig. 3. Map of the location of participants (archive of New York Public Library: New York World's Fair 1964-1965 Corporation Collection)

Fig. 4. The Concrete Era Magazine, August 1963, p.13 (archive of New York Public Library: New York World's Fair 1964-1965 Corporation Collection)

Fig. 5. Photo courtesy of New York Public Library: New York World's Fair 1964-1965 Corporation Collection

\section{Notes}

*1) List of participations could be seen in Kurniawan, Harry: The Architecture Explained by President Sukarno -Indonesian Pavilion In 1964 New York World's Fair, Part 1, AIJ Journal of Technology and Design, Vol. 24, No. 58, 2018.10, p. 1280 (http://doi.org/10.3130/aijt.24.1279)

*2) Demokrasi Terpimpin is Indonesian term for democracy style directed by Sukarno started in 1956 and was officially marked by the issuance of a Dekrit Presiden (Presidential Decree) No. 5/1959. It was continued till 1965. In this system, the function of parliament was eliminated and took over by The Guider. The Guider who has strong leadership will 'summarize the points into a compromise palatable to each faction'. Then Sukarno, as a citizen, appointed himself as The Guider. See Sukarno's explanation on Demokrasi Terpimpin in Adams, Cindy: Sukarno: An Autobiography, Gunung Agung, 1965, pp. 278-279

*3) As explained by Kusno, 2000, p. 51

*4) Delivered in his speech on groundbreaking ceremony of the Indonesia Pavilion (see New York World's Fair 1964-1965 Corporation (1963a), p. 4)

*5) As explained by Major Saudin Sagiman, the head of public relations of The Indonesian New York World's Fair Committee, in Harian Merdeka (1964)

*6) As quoted from Ho, 1963

*7) As was explained by Sri Sultan Hamengku Buwono IX — Commissioner General for the Pavilion of Indonesia—during his speech on groundbreaking ceremony of Indonesia Pavilion. (see New York World's Fair 1964-1965 Corporation (1963a), p. 4)

*8) As explained by President Sukarno in his welcome speech for returned NYWF delegates (see Sukarno, 1964)

*9) As concluded from Harian Merdeka (1964) and The Information Division of the Indonesian NYWF Committee (1964)

*10) The 'ultra-modern' phrase was delivered by Hamilton Wright Organization: Indonesia Sums up life in Pavilion of Past and Present, New York: Hamilton Wright Organization, 1964.1.00. p. 1

*11) Candi Bentar is a monumental structure in Balinese architecture that functioned as gateway.

*12) Meru tower is a wooden pagoda-like structure found in a Balinese temple.

*13) As reported by Caro, Robert A.: Indo Blows Top at Fair at High Cost to Rip Down, Nonlewsday, 1965.6.7, p. 5

*14) As reported by Charles Poletti's letter to Mr. S. Haditirto, 1964.9.4 (Archive of New York World's Fair 1964-1965 Corporation Collection at New York Public Library)

*15) Quoted from Adams, 1965, p. 70 
*16) Leclerc quoted Sukarno's Genti Suara Revolusi Indonesia speech on August 17, 1963 said: "Revolution is destruction and construction (pembangunan). Pembangunan requires creativity, and architect-minded people”. (See Leclerc, 1993, p. 53)

*17) As quoted from Sukarno, 1963, p. 42

*18) Read also two notes from Sukarno to Henk Ngantung about the need of beautiful city for its citizen on Damais, 1977, pp. 155-158

*19) As quoted from Silver, 2008, p. 100

*20) See Sukarno, 1962, pp.27-28. Sukarno succeed to influence Indonesian, as understood from written article 'Brasilia Ibukota Brasilia (Brasilia the capital of Brasilia)' published by 'Star' magazine, No. 741, March 12, 1960, pp.41-42, 47. This article illustrated wishes of Indonesians to immigrate to Brasilia.

*21) As explained in Pusat Dokumentasi Arsitektur, 2012, p. 61

*22) Read Henk Ngantung's comment about the importance of Sukarno's appearance on those projects on Damais, 1977, pp. 170-171 and p. 179. The initial approval of Sukarno that could be found on the design documents could be seen either as a proof of his involvement, such as on the design of the statue of Tugu Pembebasan Irian Barat (see Damais, 1977, p. 192) and on the image of Wisma Nusantara (see Damais, 1977, p. 230)

*23) At the beginning, the idea to build a tugu/obelisk was initiated by a group of people to commemorate the proclamation of independence on August 17, 1945 (Salam, 1989, pp. 17-18)

*24) Sukarno was involved as chairman of the jury committee. He gave a description about the importance and grandeur of Masjid Istiqlal in his speech during the announcement of the competition's winner (see Aboebakar, H.: Sedjarah Mesjid dan Amal Ibadah Dalamnja (The History of Mosque and the Worship in it), Djakarta-Banjarmasin: Fa. Toko Buku "Adil", 1955, pp. 265-268)

*25) Edhi Sunarso - the sculptor of the statue - explained in 'For Future Generations' articles, published in Endarmoko, Eko and Dewanto, Nirwan (ed.), Monumen: Edhi Sunarso, Jakarta, Galeri Salihara, 2010, p. 78. He also explained about other projects that directly ordered by Sukarno in this book

*26) See Damais, 1977, p. 230

*27) The sketch could be seen in Susanto (ed.), 2010, p. 136

*28) Photos and stories of Sukarno's visits to the construction site could be found in books, such as Salam, 1989; or Susanto (ed.), 2010

*29) As explained in Endarmoko, Eko and Dewanto, Nirwan (ed.), 2010, pp. 78-79

*30) See Damais, 1977, p.230; Endarmoko, Eko and Dewanto, Nirwan (ed.), 2010; Susanto (ed.), 2010; and 'Suluh Indonesia' Newspaper, 1964.4.21 to find several examples of it

*31) See Sukarno, 1964 for complete narration

*32) Read also Kalb, Bernard: Sukarno Chooses Site at 1964 Fair, New York: New York Times, September 16, 1961, p.21(Archive of New York World's Fair 1964-1965 Corporation at New York Public Library)

*33) As written in a letter from Sutomo Josowidigdo, Act. Consul-General of Indonesian in New York, to Mr. William Whipple, Jr, dated October 31 , 1963 (Archive of New York World's Fair 1964-1965 Corporation at New York Public Library)

*34) The used of Sukarno' speech as the brief of a project has been demonstrated earlier in the final design of Tugu Nasional proposed by architect R.M. Soedarsono (see Salam, 1989, pp. 24-28). Further explanation of the translation of the speech into the design of the Indonesian Pavilion can be read in Kurniawan, 2018

*35) See 'Paviljun Indonesia Salah Satu Front Terdepan untuk Kumandangkan dan Mentjanankan Revolusi Kita (Indonesian Pavilion: One of the Foremost Fronts to Chant and Proclaim Our Revoultion)' article, Harian Merdeka, 1964.6.22, p. 2 (in Indonesia)

*36) As written in a telegram No. 102790/M/PERDATAM/62 from Chairul Saleh to Governor Poletti which was dated September 19, 1962 (Archive of New York World's Fair 1964-1965 Corporation at New York Public Library)

*37) As reported by Levick, L.E: Spirit of Indonesia, N.Y. American, p.7, 1964.8.1

*38) As explained by Soetarao Haditiro-Commission Executive Director and reported in Saphiro, Hal: Shuttered Indonesian Pavilion Will Be Sent Back to Jakarta (M2.020 Archive of New York World's Fair 1964-1965 Corporation at New York Public Library)

*39) See explanation from Leclerc, 1993: p. 52

*40) Sukarno reminded us about the capability of the ancestor to build several grandeur monuments, such as Borobudur and Prambanan. He delivered this message in his speech at the groundbreaking ceremony of Masjid Istiqlal in 1961 (see Susanto (ed.), 2010, p. 145)

*41) As delivered by Sukarno during the briefing of national competition for a national monument on 10 May 1960, (See Leclerc, 1993, p. 41)

*42) Quoted from Kusno, 2000, p. 56

*43) Quoted from Leclerc, 1993, p. 41

*44) The mention of the title Sultan of Yogyakarta for HB IX was written at the Program for Indonesian Groundbreaking made by New York Fair 1964-1965 Corporation (Archive of New York World's Fair 1964-1965 Corporation Collection at New York Public Library). Ho (1963) either explained that the appointment of HB IX was to indicate the importance Indonesia was attaching to its appearance at the fair.

*45) As explained by Holston, James: The Modernist City: An Anthropological Critique of Brasilia, Chicago: The University of Chicago Press, 1989, p. 150

*46) See Sukarno's vision about national monument in the speech of President Sukarno at the meeting with participants of the competition of the Tugu Nasional Project at Istana Negara Jakarta on June 27, 1960, as quoted from Salam, 1989, p. 23

*47) This idea was delivered by Bernard Tschumi in Architecture and Disjunction as quoted by Forty, 2000, p. 149

*48) As quoted from Forty, 2000, p. 161

*49) See Sukarno's Tugu Kepribadian Yang Melambangkan Revolusi (Personality Monument that Symbolizes the Revolution) speech on November 17, 1960 that written in Salam, 1989, p. 24

*50) As seen in Figure 3, the final site selected by President Sukarno was much closer to the U.S.S.R lot than a lot recommended by Allen E. Beach or Block 30-the left half selected by an Indonesian participation committee member. This selection seemed to be taken by Sukarno to get a bigger lot than the two recommended lots. This 40-square-foot lot was twice bigger than what was planned by the Indonesian government earlier, and even Sukarno (1964, p.1) still expressed his regret in not selecting a much bigger lot for the Indonesian Pavilion.

*51) As quoted from the 'Minutes of Conformity Committee Meeting-Indonesian Pavilion \#C-359' April 30, 1963 signed by W.E. Potter, Chairman of Conformity Committee.

*52) Quoted from Leclerc, 1993, p. 42 


\section{和文要約}

1964 年ニューヨーク万国博覧会におけるインドネシアパビリ オンは 1961 年から 1964 年にかけてデザイン、建設された。そして インドネシアでは、ちょうど同時期に国家建設事業の元で建造物や 記念碑、インフラの建設がピークを迎えていた。特徽的な建造物を 数多く残すこととなる国家建設事業は 1957 年から 65 年にかけて指 導制民主主義を強化するための一連の建設プロジェクトとして知ら れる。国家建設事業の目的は国家の規律、および国際的な認知度を 高める必要性を示寸ことであった。記念碑的建設プロジェクトのい くつかは、独立後間もないインドネシアにおいて政治的闘争の中心 であったジャカルタに建設され、ジャカルタは他の都市の模範とし て、また国際社会における新興勢力として、あるいは国家の玄関口 として国を牽引する都市への変貌が期待された。国家建設事業は、 当時西欧をはじめ多くの国の潮流であった近代的な建築言語を建設 プロジェクトに翻訳し直すことであった。スカルノはこのような近 代的な建築言語を「かつての植民地時代のイメージを払拭する手 段」とみなした。

実施された国家建設事業の戦略的なデザイン手法には近代建築 に対する感嘆が見いだせる。例えば、ゲロラ・アジア・スタジアム、 トゥグナショナルトゥグ・ディルガンタラ、トゥグ・プンベバサ ン・イリアンバラット、そしてトゥグ・スラマ・ダタンに見られる ように建物を敷地の中心に配置すること、またはホテルインドネシ ア、サリナデパート、マスジット・イスティクラル、グドゥン・ポ ラ、そしてチョネフォビルディングのように敷地入り口から距離を 置く。このことによって建築物を周囲の環境から切り離された立体 感のある彫刻のように見せる。ミニマムな幾何学による近代的な造 形は多くの機能的、記念碑的な建築に適用され、斬新な印象を与え た。一方いくつかの建築には彫刻的な造形が用いられ、使用者や鑑 賞者に対し予想を超えた意味を想起させた。これらの近代的な建築 造形では、当時インドネシアで一般的に用いられていた三角形、あ るいはピラミッド型の屋根の造形や、粘土、木、葈などの材料を刷 新することを目的として、コンクリートや鉄による屋根形状が採用 された。また、インドネシアの彫刻芸術は建築やランドスケープの デザインの一部として用いられることもあった。トゥグ・ディルガ ンタラ、トゥグ・プンベバサン・イリアン・バラット、そしてトゥ グ・スラマ・ダタンでは人物像、トゥグ・ナショナルでは炎のよう な彫刻が取り付けられるなど記念碑的建造物には何かしらの彫刻が 施されている。さらには、より象徴性を強化するために建物の周囲 に小さい像や彫刻が置かれるものもあった。

ニューヨーク万国博覧会におけるインドネシアパビリオンは 40, 000 平方フィート $\left(12,192 \mathrm{~m}^{2}\right)$ の敷地に建つ 30,730 平方フィー 卜 $\left(9366 \mathrm{~m}^{2}\right)$ の二階建て建造物で、建設に 250 万ドルを費やした。 パビリオンは、敷地のゲートとしての 86 フィート $(26 \mathrm{~m})$ の高さの チャンディ・ベンタル、インドネシアの水の国としてのイメージや 雰囲気を作り出寸ために設けられたゲートから建物に至るまでの蓮 の池、円形をした建物の二階建ての床、傘のような形状の屋根、 5 枚の花びらのように開いては軸に向かって閉じる高さ 61 フィート (18m) の屋根の梁、そして装飾としての伝統的な要素やモチーフ
といった物質的な特徴によって表現される、超近代的イメージを作 りだした。この壮大なパビリオン計画は、スカルノによって、彼の 意図を汲みながらトゥグ・ナショナルを代表とする国家的な建設分 野にかかわった経験があり、王宮付きの建築家でもあった R. M. ス ダルソノに直接委託された。インドネシアパビリオンには、他の国 家建設事業と比較してくつかの特徵が見られる。それは、ほとんど の国家建設事業がインドネシアの首都で国民闘争の中心であったジ ヤカルタで行われたのに対し、唯一の海外プロジェクトであるとい うこと、そして他の国家建設事業では永続性が意図されたのに対し、 インドネシアパビリオンが仮設的に建設されたということである。 ただし、1964 年のニューヨーク万国博覧会におけるインドネシア パビリオンは、その他の国家建設プロジェクトの延長として位置付 けることができる。近代的な建築言語や記念碑性のような共通する 基本的特徵は、スカルノの 1957-65 の指導制民主主義の手段として も用いられており、スカルノが関わった同様の設計プロセスは、全 てのプロジェクトに見いだすことができる。このようにインドネシ アのパビリオンや他の国家建設プロジェクトは、デザインそれ自体 にとどまらず、プロジェクトで同じビジョンを共有する人々を指導 制民主主義に先導するスカルノの立場を明確に示すこととなった。

インドネシアパビリオンにおけるこれらの建築的特徵から、

単なる機能的また記念碑的な制約を超えたプロジェクトであるとの 結論に至る。インドネシアパビリオンの主要な建物に大量に施され た伝統的な要素や造形のデザインには、記念碑的プロジェクトの特 徵である象徵的な彫刻が確立されたプログラムから導かれるビルデ イングタイプ特有の機能的な建物に表れている。さらにその建物に 意味性の高い形態が加わることによってそのデザインがより強化さ れた。これらは一般的な近代建築の性質には反するものと指摘され るだろう。さらにインドネシアパビリオンが持つこの独特な特徵を 国家建設事業から排除寸るのものとして扱うのではなく、スカル， が国家建設事業の目的として説明した「奮闘している人類の寸べて や新興勢力を鼓舞する狼煙、そして国家の玄関口としての役割」の 考えを支持するものであった。さらに海外という場所性、一時的で ある時間性、そして外国人という見学者の属性というインドネシア パビリオンのプロジェクト背景において、この建物の独特な姿は、 より短時間でインドネシアというものを容易に知らしめ、理解させ ることができた。そしてこの特徴は「超近代」という謳い文句を具 現化したものであり、国家建設事業の総括としてのインドネシアパ ビリオンを結論づけるものである。

(2018 年 4 月 10 日原稿受理, 2018 年 11 月 30 日採用決定) 